\title{
APLIKASI TIK TOK SEBAGAI MEDIA KAMPANYE UNTUK PENCEGAHAN PENYEBARAN COVID-19
}

\author{
Ita Suryani $^{1}$, Akhmad Zulfikri. ${ }^{2}$, Wulan Muhariani ${ }^{3}$ \\ ${ }^{1}$ Universitas Bina Sarana Informatika, ita.its@ bsi.ac.id ${ }^{1}$ \\ ${ }^{2}$ Universitas Bina Sarana Informatika, akhmadzulfikri@gmail.com ${ }^{2}$ \\ ${ }^{3}$ Universitas Bina Sarana Informatika, wulan.wmh@ @si.ac.id ${ }^{3}$
}

\begin{abstract}
ABSTRAK
Tik Tok suatu aplikasi yang saat ini digunakan oleh kalangan anak muda zaman sekarang dan digemari di dunia. Tik Tok bisa dengan mudah membuat video dengan lama tayang selama 15 detik, bisa disisipkan musik, filter, dan termasuk fitur-fitur kreatif dengan mensisipakn special effects yang menarik sehingga penggunanya bisa beraktifitas dengan beragam gaya yang menarik. Pengguna yang beraktifitas di TikTok terdorong untuk lebih menjadi content creator. Ketika semua orang tidak dapat bertemu karena adanya larangan untuk berkumpul pada masa pandemic covid-19, maka aplikasi Tik Tok menjadi cara untuk digunakan dalam mengkampanyekan akan penting di rumah saja dan selalu menerapakan protokol kesehatan 3M (memakai masker, mencuci tangan dan menjaga jarak). Tujuan penelitian ini adalah ingin mengetahui bagaimana aplikasi Tik Tok digunakan sebagai media kampanye untuk mencegah penyebaran covid-19. Penelitian yang digunakan yaitu metode studi kasus dimana penelitian yang mendapatkan data dari berbagai sumber data dan dengan berbagai alat untuk pengumpulan data. Hasil penelitiannya adalah kampanye pencegahan penyebaran covid-19 dengan memanfaatkan Tik Tok Menjadi media yang efektif dalam menyampaikan pesan kepada masyarakat akan pentingnya di rumah saja dan pentingnya menerapkan protokol kesehatan 3M (memakai masker, mencuci tangan dan menjaga jarak) hal ini terlihat dengan banyaknya kalangan masyarakat yang bergabung dalam aplikasi Tik Tok untuk kampanye \#SamaSamaDirumah dan \#PahlawanGardaDepan.
\end{abstract}

Kata kunci: Media Sosial, Tik Tok, Kampanye, Covid-19

\begin{abstract}
Tik Tok is an application that is currently used by young people today and is popular in the world. Tik Tok can easily make videos with a duration of 15 seconds, can insert music, filters, and include creative features by inserting interesting special effects so that users can do activities in a variety of interesting styles. Users who are active on TikTok are encouraged to become more content creators. When everyone cannot meet because of the prohibition on gathering during the Covid19 pandemic, the Tik Tok application is a way to campaign for important things at home and always applies the 3M health protocol (wearing masks, washing hands and keeping your distance). The purpose of this research is to find out how the Tik Tok application is used as a campaign medium to prevent the spread of covid-19. The research used is the case study method where the research gets data from various data sources and with various tools for data collection. The result of his research is a campaign to prevent the spread of covid-19 by utilizing Tik Tok to become an effective media in conveying messages to the public about the importance of being at home alone and the importance of implementing $3 M$ health protocols (wearing masks, washing hands and maintaining distance), this is evident by the large number of people in the community. who joined the Tik Tok application for the \#SamaSamaDirumah and \#PahlawanGardaDepan campaigns.
\end{abstract}

Keywords: Social Media, Tik Tok, Campaign, Covid-19

\section{PENDAHULUAN}

Pada 2 Maret lalu kasus Covid-19 pertama kali terjadi di Indonesia, dan hingga kini mengalami kenaikan secara signifikan (Bahtiar et al., 2021). Organisasi Kesehatan Dunia (WHO) telah mengubah status infeksi

ISSN: 2355-0287, e-ISSN: 2549-3299 
Covid-19 menjadi pandemic secara Internasional. Pemerintah Indonesia memberikan pernyataannya bahwa pandemi Covid-19 sebagai bencana nasional. Banyak daerah yang telah menetapkan status KLB untuk menangani pandemi tersebut.

Sejak diumumkannya pandemic Covid-19 sebagai bencana nasional, sejumlah wilayah telah menetapkan sebagai status Kejadian Luar Biasa (KLB) untuk penanganan pandemi ini. Untuk menyikapi pandemi Covid-19, diperlukan kerjasama dan kolaborasi antara pemerintah, parlemen, masyarakat, pelaku industri, akademisi dan peneliti untuk meminimalisir penyebaran pandemi ini, mencegah dan menyembuhkannya. Saat ini, penyebaran Covid-19 sudah sangat umum terjadi. Akhirnya, memaksa pemerintah mengambil kebijakan untuk menghentikan sementara kegiatan dan menerapkan PSBB (pembatasan sosial massal). Mendorong sekolah untuk menutup siswa, perusahaan bahkan industri, dan mewajibkan karyawannya untuk bekerja dari rumah (bekerja di rumah). Tujuannya untuk mengurangi penyebaran virus corona dengan mengurangi kontak publik antarpenduduk.

Pemerintah menghentikan kegiatan dan menegakkan kebijakan PSBB, mendorong orang untuk tinggal di rumah dan membatasi keluar rumah. Dan tetap menjalankan protokol Kesehatan 3M (pakai masker, hati-hati dan cuci tangan) untuk mencegah dan meminimalkan risiko penyebaran virus.

Tetapi, himbauan pemerintah belum sepenuhnya dilakukan dengan baik dan dipatuhi, karena masih banyak masyarakat yang belum menyadari akan pentingnya "di rumah saja" dan masih adanya masyarakat yang belum menerapkan protokol Kesehatan 3M (memakai masker, menjaga jaga dan mencuci tangan), sehingga jumlah masyarakat yang terpapar covid-19 semakin bertambah setiap harinya.

Di seluruh dunia, termasuk di Indonesia, pada masa pandemic Covid-19 sampai saat ini jumlah terpapar covid-19 dengan hasil positif 939.948 orang, 763.703 orang pulih dan 26.857 korban meninggal. (Mufarida, 2021)

Melihat banyaknya korban meninggal karena terpapar covid-19 tentunya banyak pihak termasuk pemerintah Indonesia melakukan berbagai untuk pencegahan penyebaran virus corona. Salah satu untuk mencegahnya adalah dengan tetap di rumah saja dan tetap menjalankan protokol kesehatan 3M.

Untuk mengkampanyekan pentingnya tetap berada di rumah dan tetap menjaga protokol Kesehatan $3 \mathrm{M}$, hal itu tentunya dapat dicapai dengan sosialisasi kepada masyarakat luas. Penggunaan media sosial seperti Tik Tok juga telah digunakan sebagai media promosi untuk mencegah penyebaran Covid-19.

Iswah (2011) Dijelaskan bahwa pengguna internet sering menggunakan media sosial sebagai sarana berkomunikasi dengan pengguna lain untuk mencegah penyebaran COVID-19. Pengguna internet biasanya menggunakan media sosial sebagai media untuk berkomunikasi dengan pengguna lain dalam bentuk publikasi atau konten (Iswah, 2011)

Dalam perkembangan media sosial, digunakan untuk berbagai keperluan, mulai dari berteman, berkampanye untuk program tertentu di bidang pendidikan, lingkungan, kemasyarakatan, agama, lingkungan, dan kesehatan hingga kegiatan promosi, pemasaran produk tertentu. atau layanan, dan publikasi (Suryani et al., 2020). Melalui media sosial, siapa pun dapat membuat, mengedit, dan mempublikasikan konten/isi berita, publikasi/promosi, artikel, foto, serta video mereka sendiri. Selain dirasa lebih fleksibel, lebih luas, juga menjadi efektif, efisien, cepat, interaktif dan beragam. Maka terkait hal ini, bagaimana memanfaatkan media sosial seperti Tik Tok, facebook, instagram atau yang lainnya digunakan sebagai media promosi, publikasi, iklan bahkan kampanye. Sebagai saluran komunikasi word-of-mouth, karena informasi mengenai produk ditempatkan pada media tersebut kemudian mengalami 
informasi yang berulang-ulang karena dapat membangkitkan minat masyarakat.

Tik Tok suatu aplikasi yang banyak digunakan oleh kalangan anak muda zaman sekarang dan diminati di dunia. Tik Tok bisa dengan mudah membuat video dengan lama tayang selama 15 detik, bisa disisipkan musik, filter, dan termasuk fitur-fitur kreatif dengan mensisipakan special effects yang menarik sehingga penggunanya bisa beraktifitas dengan beragam gaya yang menarik. Pengguna yang beraktifitas di TikTok terdorong untuk lebih menjadi content creator (Adawiyah, 2020).

Aplikasi Tik Tok sebagai salah satu media yang dapat digunakan untuk mengkampanyekan penting tetap di rumah dan selalu menjalankan protokol kesehatan 3M (memakai masker, menjaga jarak dan mencuci tangan). Ketika semua orang tidak dapat bertemu karena adanya larangan untuk berkumpul pada masa pandemic covid-19.

Seperti yang dilakukan oleh perusahaan aplikasi Tik Tok Indonesia, memanfaatkan media sosial Tik Tok dalam membantu pemerintah Indonesia untuk pencegahan penyebaran Covid-19.

Dengan adanya uraian diatas, maka penulis membahas mengenai "Aplikasi Tik Tok Sebagai Media Kampanye Untuk Pencegahan Penyebaran Covid-19".

Tujuan yang ingin dicapai penulis yaitu bagaimana aplikasi Tik Tok dapat dijadikan sebagai media kampanye dalam menyebarkan pesan kepada masyarakat agar tetap di rumah dan pentingnya menjalankan protokol kesehatan 3M.

Sejak awal, media sosial mengacu kepada strategi komunikasi dan berinteraksi. Oleh karena itu, media sosial merupakan dua (dua) metode komunikasi yang disebarkan melalui internet melalui audio, tulisan, video dan foto (Riese et al., 2010)

Media sosial adalah kumpulan aplikasi berdasarkan prinsip Web berdasarkan ide dan teknologi Internet 2.0, yang memungkinkan terciptanya prinsip konten yang dibuat oleh penggunanya. (Kaplan \& Haenlein, 2010).

(Puntoadi, 2011) menjelaskan bahwa media sosial yaitu media online dan dapat digunakan secara partisipatif yang mempublikasikan video, dberita, dan foto. Beberapa jenis aplikasi media sosial antara lain bookmark, berbagi konten, Wiki, Facebook, menghubungkan, membuat komentar, dan blog.

Beberapa fungsi sosial media (Wijayanto, 2012) sebagai berikut:

1. Media yang memiliki tujuan untuk menggunakan teknologi Internet dan Web untuk memperluas interaksi sosial manusia.

2. Media yang telah sukses mengubah komunikasi langsung dengan media penyiaran dari organisasi-organisasi media ke khalayak yang besar, dan berubah menjadi dialog multi-penonton.

3. Media yang mendukung demokratisasi informasi dan pengetahuan

Media sosial merupakan media komunikasi, dan opini masyarakat dapat dibentuk melalui media populer atau online. Hasil dari pemberitaan merupakan citra yang positif, dan fungsi media untuk membentuk opini publik sebagaimana dikemukakan oleh Alexis S. Tan. Isi spesifiknya adalah sebagai berikut:

1. Berkomitmen untuk memberikan informasi, memahami lingkungan, menguji realitas, dan membuat keputusan.

2. Melalui fungsi pendidikan, media menyebarkan pengetahuan dan keterampilan yang bermanfaat untuk memainkan peran yang efektif dalam masyarakat dan mempelajari nilai-nilai dan perilaku yang sesuai untuk penerimaan sosial.

3. Dengan fungsi persuasif, media dapat mengambil keputusan dan mengadopsi nilai, perilaku dan aturan yang sesuai untuk penerimaan sosial.

4. Fitur menarik memenuhi kebutuhan komunikator, menyegarkan orang, mengendurkan saraf, menghibur dan mengalihkan masalah (Nurdin, 2007)

Roger dan Storey (Venus, 2004) Kampanye merupakan "rangkaian kegiatan komunikasi yang sistematis dan terencana, tujuannya dilakukan secara terus menerus 
pada waktu tertentu agar berdampak tertentu pada sejumlah besar khalayak". Setiap kegiatan kampanye mencakup empat hal: 1). Kegiatan yang dilakukan untuk menghasilkan dampak atau akibat. 2). Sasaran dalam jumlah besar. 3). Latihan untuk jangka waktu tertentu. 4). Kegiatan dalam komunikasi yang direncanakan.

Beberapa jenis kegiatan pemasaran menurut (Ruslan, 2008), sebagai berikut:

1. Kegiatan pemasaran yang berorientasi produk

Kegiatan dalam kegiatan pemasaran menghasilkan produk yang biasanya muncul dalam lingkungan bisnis.

2. Kampanye berorientasi calon/kandidat ditujukan untuk kandidat yang ingin kekuasaan.

3. Kampanye ideologis atau berorientasi tujuan dapat mencapai tujuan, biasanya terkait dengan perubahan sosial.

Venus (2004) mengemukakan tujuan dari kampaye mempunyai 3 tujuan: (Venus, 2004)

1. Perubahan keyakinan, dan menjadi pengetahuan sadar atau kenaikan atau khalayak kognitif tentang masalah tertentu.

2. Tujuannya adalah untuk menghasilkan simpati, cinta, dan menjadi penonton yang peduli tentang masalah itu adalah masalah dalam kampanye. Ada perubahan sikap.

3. Diharapkan munculnya tindakan oleh target sasaran kampanye pada tahap ini, untuk mengubah perilaku dengan terukur dan konkret.

\section{METODOLOGI PENELITIAN}

Penelitian menggunakan metode studi kasus yakni metode riset yang menjelaskan secara komprehensif. Pada metode ini membutuhkan berbagai macam instrument dan berbagai sumber data dalam pengumpulan data. Oleh karena itu, dokumentasi-dokumentasi, wawancara secara mendalam, kuesioner hasil survei, peninjauan secara langsung, dan bukti yang digunakan oleh peneliti. (Kriyantono, 2006)

Dalam penentuan hasil atau kesimpulan pada penelitian kualitatif pemikiran secara induktif sangat menonjol (Pawito, 2007). Maka, pada penelitian kualitatif diharapkan dapat memberikan hasil deskripsi mendalam tentang perilaku, tulisan, dan ucapan, dan Anda dapat mengamati dan mempelajari perilaku, tulisan, dan ucapan ini dari perspektif yang komprehensif, komprehensif, dan holistik dari individu, kelompok, organisasi, dan masyarakat tertentu yang sedang dipelajari. Objek penelitian yaitu membahas mengenai Aplikasi Tik Tok Sebagai Media Kampanye Untuk Pencegahan Covid-19.

Moleong mengatakan dalam penelitian kualitatif, ciri tersebut salah satunya deskriptif, dan data yang diperoleh berupa teks dan gambar. Maka hasilnya, memberikan deskripsi atau gambaran dalam penyajian laporan penelitian berisi mengenai kutipan data.

Dalam penelitian ini data diperoleh melalui penelitian kepustakaan. Informasi berkaitan dengan data tersebut dapat diperoleh oleh peneliti berdasarkan temuan hasil penelitian, disertasi, tesis, karangan ilmiah.

\section{HASIL DAN PEMBAHASAN}

Wabah pandemi Covid-19 telah mengubah perilaku masyarakat Indonesia, dan sudah menjadi hal yang lumrah ketika orang rutin mengonsumsi konten online. Menurut survei yang dilakukan Mckinsey and Company pada Juli 2020, 37\% publik semakin mencari peluang hiburan di rumah, sementara $28 \%$ publik semakin sering menonton media digital atau streaming konten. Hasil survei menunjukkan bahwa $11 \%$ responden mengaku menghabiskan lebih banyak waktu pada aplikasi Tik Tok selama pandemi Covid-19.

Konten yang tersedia di Tik Tok dapat membawa kegembiraan sehingga dapat meningkatkan imun bagi penggunanya di masa pandemi ini. Hasil survei menunjukkan bahwa $70 \%$ dari pengguna Tik Tok optimistis jika dunia dapat mengatasi kondisi pandemi,

Dukungan musik yang banyak dan special effect yang unik dan menarik membuat Aplikasi Tik Tok dapat membangun lingkungan yang mendukung 
kesehatan mental sehingga penggunanya dapat menghasilkan konten yang menarik.

Sebagai platform digital, Tik Tok Indonesia bekerjasama dngan WHO untuk menyampaikan informasi yang bermanfaat kepada pengguna Tik Tok terkait virus corona dan bekerjasama dengan BNPB, Gugus Tugas Percepatan Penangganan Covid-19 serta beberapa kementerian dan lembaga negara lainnya dalam membantu pencegahan covid- 19 .

Tik Tok Indonesia sudah beberapa kali melakukan kegiatan kampanye, salah satunya adalah kampanye \#SamaSamaDirumah tertujuan untuk mengajak masyarakat melakukan berbagai kegiatan produktif selama tetap di rumah, dan mendapatkan pengguna lain untuk tetap aktif dan produktif selama masa karantina serta kampanye \#PahlawanGardaDepan merupakan salah satu bentuk apresiasi Tik Tok Indonesia kepada para tenaga medis dalam melawan pandemi covid-19 sebagai garda terdepan.

Kampanye\#PahlawanGardaDepan sudah dilihat di Tik Tok sebanyak 1,2 miliar kali sedangkan kampanye \#SamaSamaDirumah sudah dilihat 38,6 miliar kali di TikTok. (Yehezkiel Sitinjak, 2020)

Sehingga dengan hal ini Tik Tok Indoensia telah menunjukkan dan memberikan contoh nyata kolaborasi, dalam menyediakan konten yang kredibel dan berkualitas bagi pengguna tapi juga berkontribusi bagi tenaga medis di Indonesia.

Kampanye \#SamaSamaDirumah, merupakan komitmen dari Tik Tok Indonesia dalam mendukung himbauan dari pemerintah yang mengajak masyarakat untuk tetap dirumah saja melalui sajian konten positif dan bermanfaat bagi para pengguna TikTok di Indonesia.

Dalam kampanye

\#SamaSamaDirumah, ada beberapa hal yang dapat dilakukan pada aplikasi Tik Tok tersebut antara lain:
1. Video tutorial membuat kopi dalgona dan belajar memasak;

2. Seru dan sehat bersama keluarga;

3. Pindah ke kelas online;

4. Nyanyi, duet, bisa kok dari rumah!; dan

5. \#LiveDiRumah
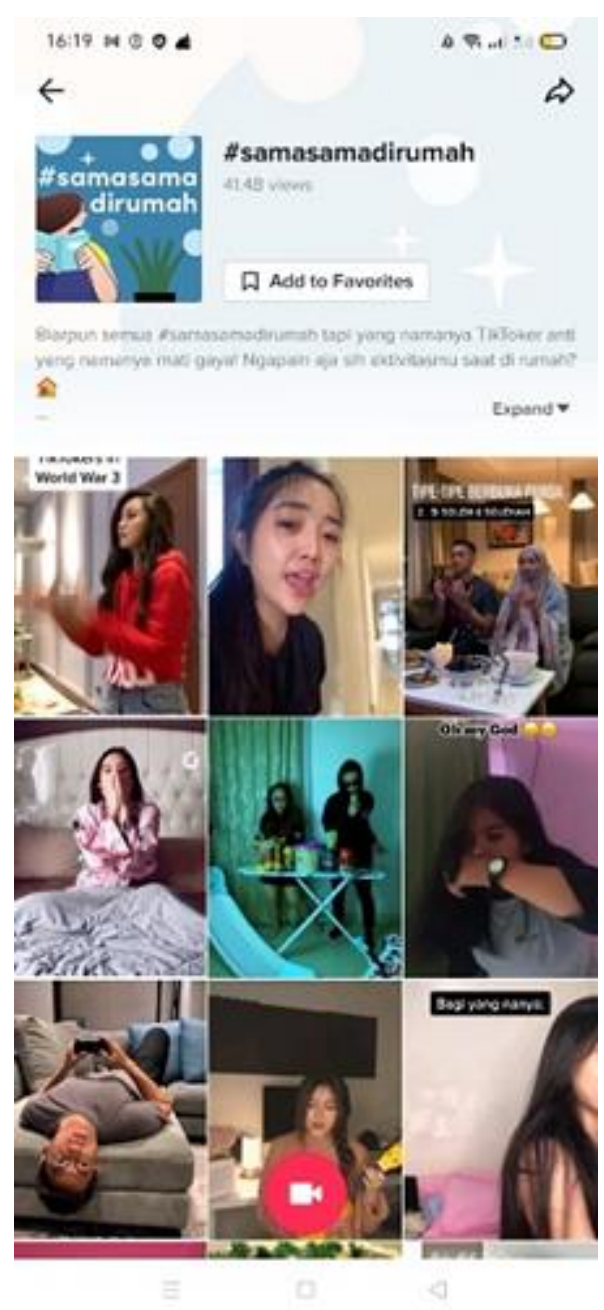

Gambar 1. Aktifitas pengguna Tik Tok dalam kampanye \#SamaSamaDirumah
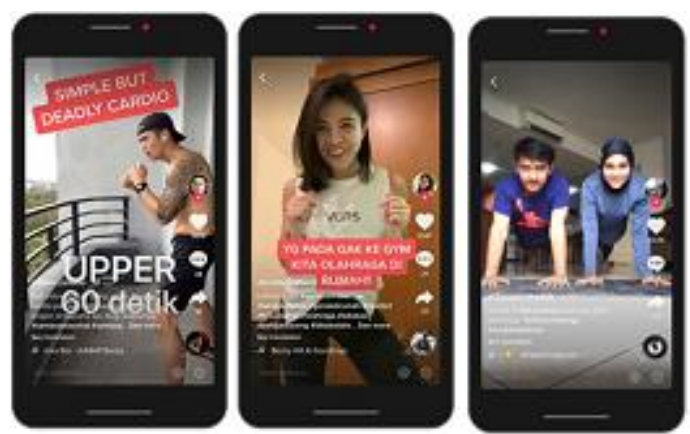
Gambar 2. melakukan aktifitas seru dan sehat bersama keluarga
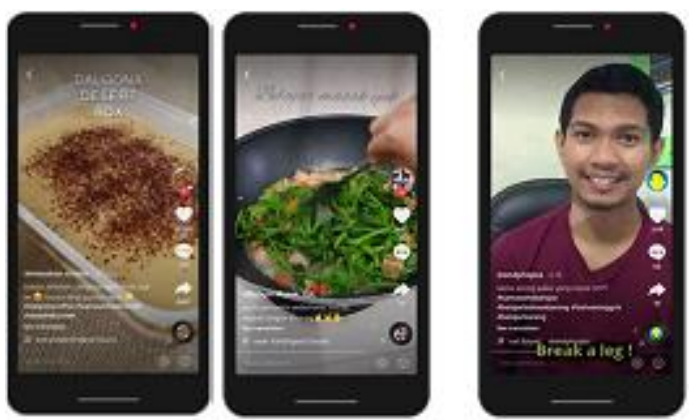

Gambar 3. melakukan aktivitas "membuat kopi Dalgona dan Belajar memasak"
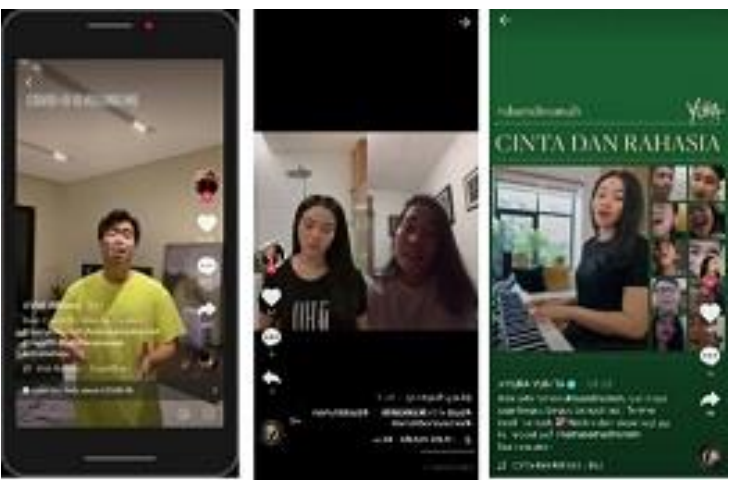

Gambar 4. melakukan aktifitas " Nyanyi, duet, bisa kok dari rumah"

Sumber: https://vt.tiktok.com/ZSwxgkFE/

Banyak keluarga di Indonesia yang kehilangan keluarga tercinta, tenaga media menjadi garda terdepan yang berjuang untuk melawan pandemi ini, dan banyak dari mereka yang mempertaruhkan nyawanya.

Berdasarkan hal itu, Tik Tok Indonesia, melakukan kampanye \#PahlawanGardaDepan, menunjukkan rasa terima kasih dan apresiasi kepada tenaga medis yang saat ini sedang berjuang menghadapi pandemi Covid-19 dan juga menyadarkan masyarakat akan pentingnya menerapkan protokol kesehatan 3M (memakai masker, mencuci tangan dan menjaga jarak).
Pada

kampanye \#PahlawanGardaDepan, TikTok mengajak pengguna untuk bergabung dalam kampanye ini melalui kegiatan yang mengajak pengguna Tik Tok untuk berbagi informasi dan pesan penting seputar virus corona atau Covid-19 mengenai langkah pencegahan, cara memakai masker yang benar, memberikan informasi bagaimana menjaga kesehatan serta memberikan semangat kepada para tenaga medis dalam menjalankan tugasnya.
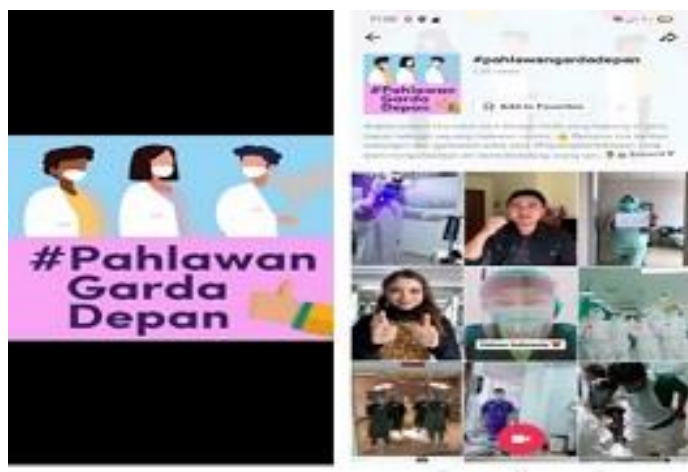

Gambar 5. logo dan aktifitas pada kampanye \#PahlawanGardaDepan

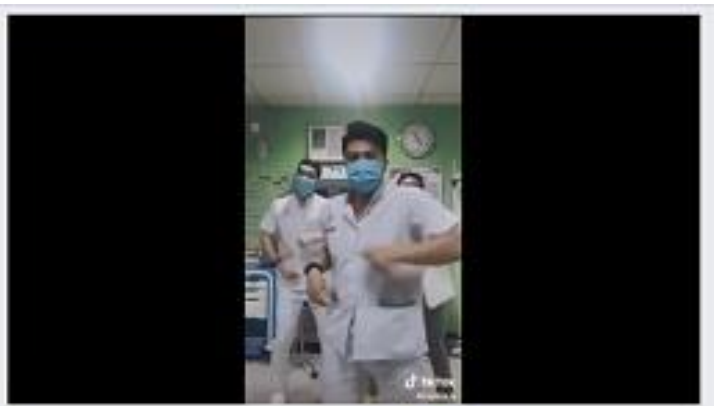

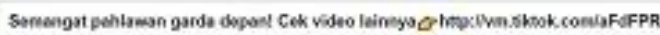

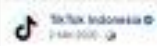

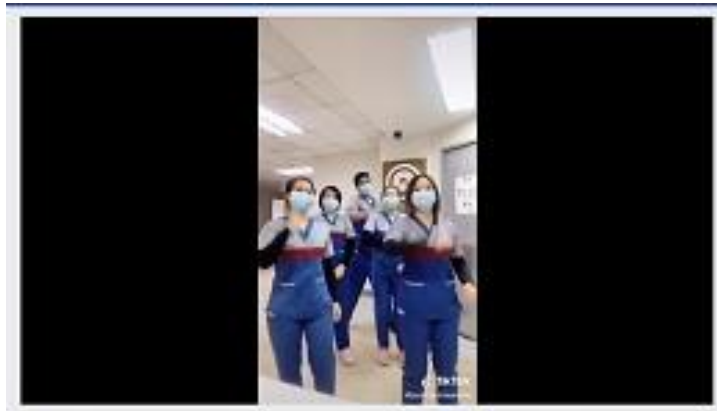

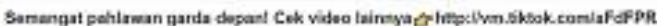

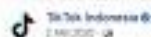




\section{Jurnal Ilmu Komunikasi, Vol.8 No.1 April 2021}

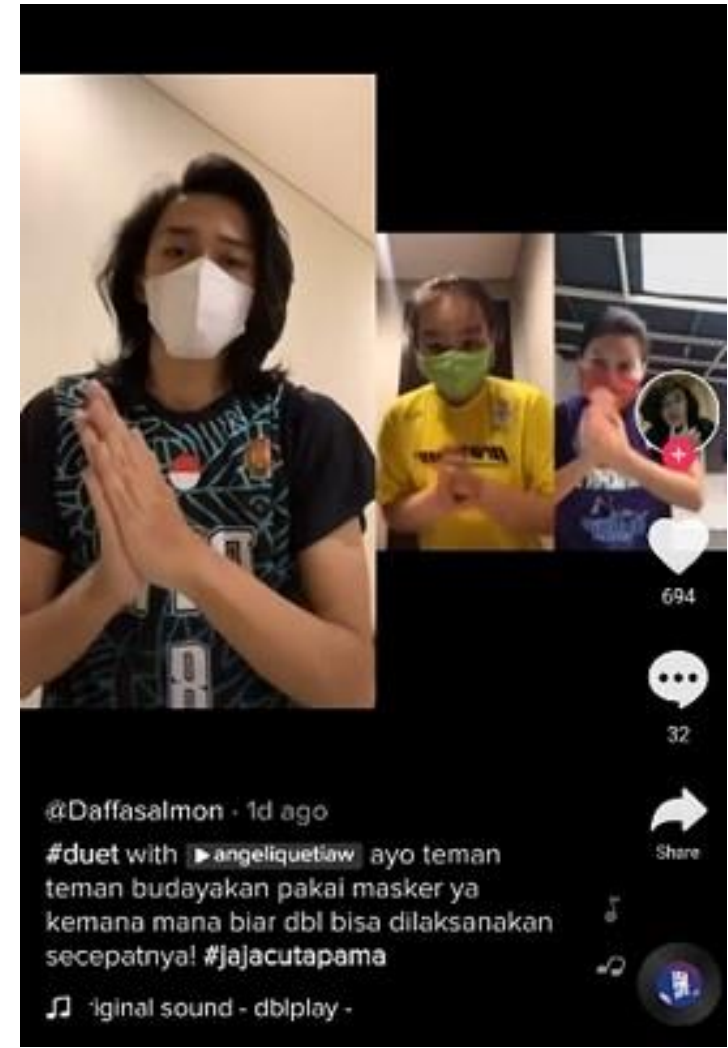

Gambar 6. Aktifitas pengguna Tik Tok dalam kampanye \#PahlawanGardaDepan untuk selalu menggunakan masker

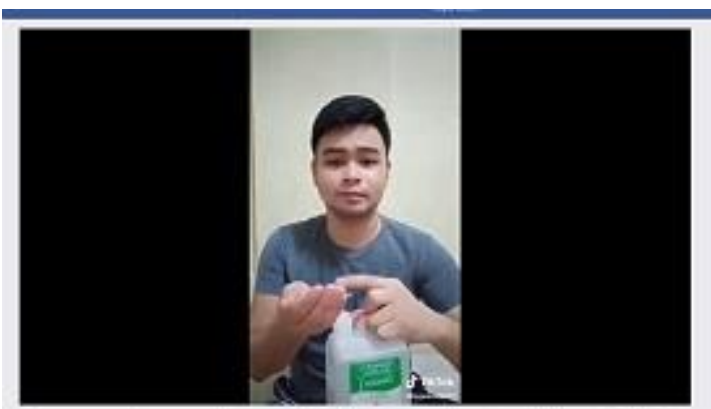

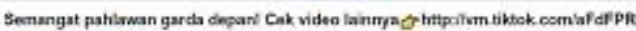

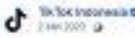

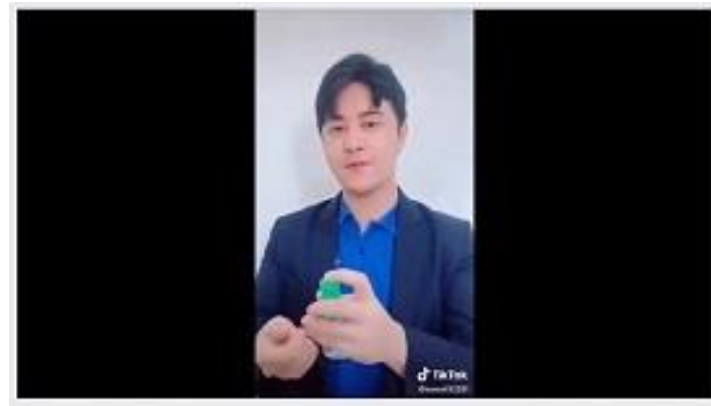

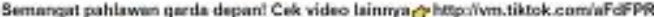

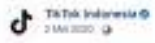

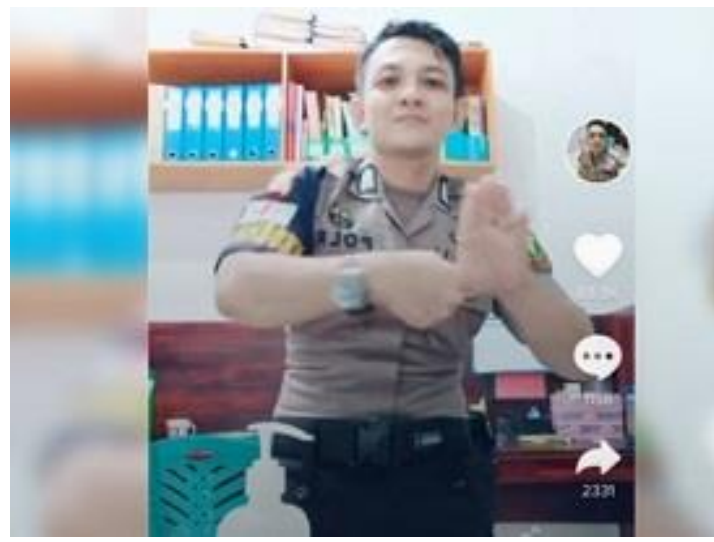

Gambar 7. Aktifitas para pengguna Tik Tok dalam kampanye \#PahlawanGardaDepan untuk selalu menggunakan handsanitizer dan tutorial gerakan cuci tangan yang benar

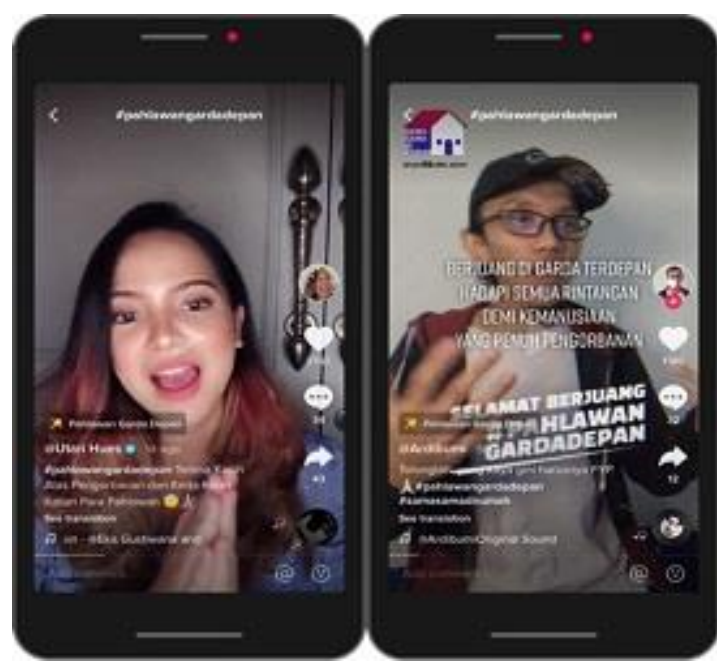

Gambar 8. Aktifitas Utari Hues dan Ardi Bumi dalam kampanye \#PahlawanGardaDepan bernyanyi duet 
sebagai bentuk ucapan terima kasih kepada para tenaga medis

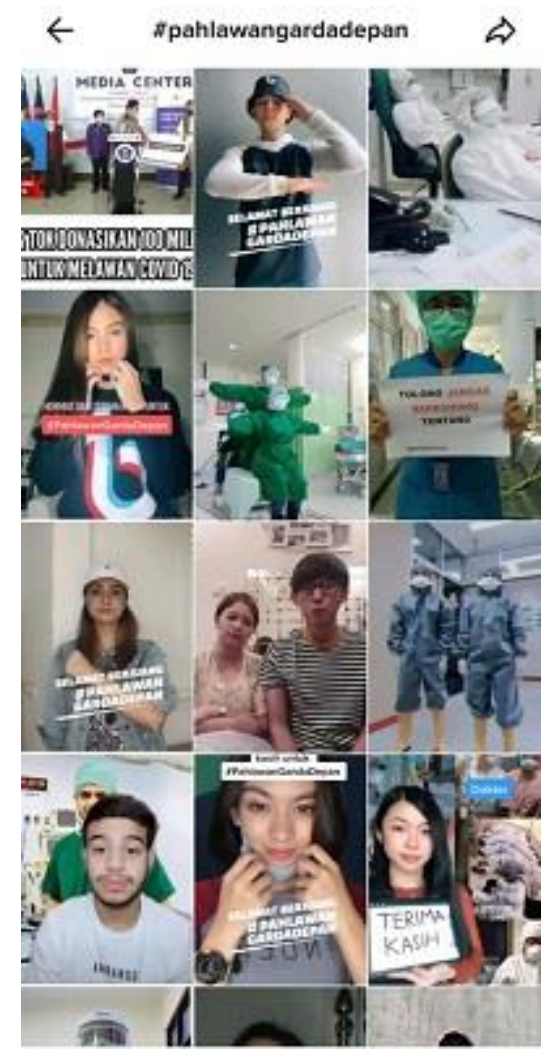

Gambar 9. aktifitas para artis, selebgram dan youtuber yang tergabung dalam kampanye \#PahlawanGardaDepan

Sumber: http://vm.tiktok.com/aFdFPR/

\section{KESIMPULAN}

Aplikasi Tik Tok kini sangat digandrungi dan menjadi trend semua kalangan di Indonesia, mulai dari orang tua, kaum millennials, sampai anak-anak kecil jaman now. Aplikasi ini memberikan sesuatu hal yang unik dan menarik sehingga pengguna dapat dengan mudah membuat video pendek yang di dukung dengan musik yang banyak, sehingga menghasilkan performa yang bagus dan menarik. Seiring dengan perkembangannya, aplikasi Tik Tok tidak hanya memberikan hiburan, namun juga sebagai media edukasi seperti digunakanya aplikasi Tik Tok sebagai media kampanye untuk pencegahan penyebaran covid-19. Berdasarkan hasil penelitian, untuk membantu pemerintah dalam mencegah penyebaran covid-19, Tik Tok Indonesia memanfaatkan Tik Tok sebagai media kampanyenya. Dengan mengusung tema kampanye \#SamaSamaDirumah dan \#PahlawanGardaDepan, Tik Tok menjadi media yang efektif dalam menyampaikan pesan kepada masyarakat akan pentingnya di rumah saja dan pentingnya menerapkan protokol kesehatan 3M dan sebagai bentuk nyata bahwa Tik Tok Indonesia berkontribusi terhadap kesehatan masyarakat Indonesia dan para tenaga medis yang disajikan melalui konten positif, ringan dan mudah dicerna serta bermanfaat bagi para pengguna Tik Tok di Indonesia.

\section{REFERENSI}

Adawiyah, D. P. R. (2020). Pengaruh Penggunaan Aplikasi TikTok Terhadap Kepercayaan Diri Remaja di Kabupaten Sampang. Jurnal Komunikasi, 14(2), 135-148.

Bahtiar, H., Ariyanti, M., \& Supriyadi, S. (2021). Promosi Kesehatan Tentang Covid-19, Pencegahan Dan Penanganan Hipertensi Pada Lansia. Jurnal Lentera, 1(1), 74-80. http://journal.stikesyarsimataram.ac.id/i ndex.php/lentera/article/view/89

Iswah, D. (2011). Panduan Praktis Mengoptimalkan Twitter. Mediakita.

Kaplan, A. M., \& Haenlein, M. (2010). Users of the world, unite! The challenges and opportunities of Social Media. Business Horizons, 53(1), 5968.

https://doi.org/10.1016/j.bushor.2009. 09.003

Kriyantono, R. (2006). Teknik Riset Komunikasi. Kencana Prenada Media Group.

Mufarida, B. (2021). Update Corona 20 Januari 2021: Positif 939.948 Orang, 763.703 Sembuh dan 26.857 Meninggal. Okezone.Com, Nasional. 
Nurdin, N. (2007). Pengantar Komunikasi Massa. PT Rajagrafindo Persada.

Pawito, P. (2007). Penelitian Komunikasi Kualitatif. LKIS Pelangi Aksara.

Riese, M., Pennisi, L. A., \& Major, A. L. (2010). Using social media to market yourself. Communities \& Leadership Small Business/Entrepreneurship, 108(5), 33. https://extensionpublications.unl.edu/assets/ pdf/g2029.pdf

Ruslan, R. (2008). Kiat dan Strategi Kampanye Public Relation (1st ed.). Rajagrafindo Persada. http://www.rajagrafindo.co.id/produk/kiatdan-strategi-kampanye-public-relation/

Suryani, I., Sagiyanto, A., \& Supriyanto, I. (2020). Kampanye Komunikasi Viral $\mathrm{Bu}$ Tejo Sebagai Endorser Brand Produk Kacang Garuda Koro PT Garudafood. Journal Komunikasi, $\quad 1(2), \quad$ 170-179. https://ejournal.bsi.ac.id/ejurnal/index.php/jk om/article/view/8987

Venus, A. (2004). Manajemen Kampanye; Panduan Teoritis Dan Praktis Dalam Mengefektifkan Kampanye Komunikasi. Simbiosa Rekatama Media.

Wijayanto, F. (2012). Social Media: Definisi, Fungsi, Karakteristik. Prezi. https://prezi.com/vddmcub_-ss_/socialmedia-definisi-fungsi-

karakteristik/?fallback=1

Yehezkiel Sitinjak. (2020, October). Relevan dan Menyenangkan, TikTok Tumbuh di Masa Covid-19. Theiconomics.Com.

\section{PROFIL PENULIS}

Ita Suryani, S.Sos, M.I.Kom. Dosen aktif Program Studi Hubungan Masyarakat Universitas Bina Sarana Informatika dari tahun 2007 sampai dengan sekarang. Menjadi pembicara, moderator dan master of ceremony pada beberapa kegiatan seminar/webinar. Menjadi juri pada acara "The Best Contact Center Indonesia" yang diselenggrakan oleh Indonesia Contact Center Association (ICCA). Menulis beberapa jurnal yang telah dipublikasikan dan sebagai penulis buku ajar "Penulisan Naskah Public Relations I \& II.

\begin{abstract}
Akhmad Zulfikri S.Ikom, Dosen Program Hubungan Masyarakat Universitas Bina Sarana Informatika sejak tahun 2020 dan juga sedang menempuh pendidikan Magister Manajemen di Univeristas Esa Unggul Jakarta, selain itu bekerja di PT Hotel Indonesia Natour (Persero) sebagai Corporate Secretary. Saat ini aktif pada organisasi kehumasan dan organisasi pariwisata di Indonesia antara lain PERHUMAS, Forum Humas BUMN, Bakohumas serta PHRI. Pada tahun 2005 pernah menjadi finalis Abang None Jakarta dan pada tahun 2018 mendapatkan penghargaan Icon PR Indonesia yang diselenggarakan oleh Majalah PR Indonesia, serta aktif menulis opini terkait pariwisata dan komunikasi di https://terbangkebulan.com/ serta https://akhmadzulfikri.com/
\end{abstract}

Wulan Muhariani, M.I.Kom, Seorang praktisi komunikasi yang sudah berpengalaman selama 10 tahun di dunia agency maupun korporasi. Gelar Sarjana dan Magister Ilmu Komunikasi didapatkan Wulan dari Universitas Mercu Buana dengan gelar Cum Laude. Wulan juga pernah dinobatkan sebagai wisudawati terbaik dari Bina Sarana Informatika ketika menempuh pendidikan Diploma 3. Saat ini Wulan bekerja di salah satu perusahaan transportasi darat ternama di Indonesia dan Wulan juga merupakan salah satu dosen di Program Studi Hubungan Masyarakat Universitas Bina Sarana Informatika. Spesialisasi Wulan ada di komunikasi krisis, Corporate Social Responsibility (CSR), internal communications, Public Relations, marketing communications, media \& community relations. Selain itu Wulan juga aktif sebagai blogger di blog pribadinya www.mwulan.com 